\title{
Molecular characterisation of french olive cultivars using microsatellites: towards the establishment of a reference genotype $d$
}

Oléagineux, Corps Gras, Lipides. Volume 11, Numéro 3, 225-9, MAI-JUIN 2004, Qualité

Auteur(s) : Bouchaïb KHADARI, Nathalie MOUTIER, Sara PINCZON DU SEL, Françoise DOSBA

UMR 1098 Biologie du développement des espèces pérennes cultivées (BEPC). Equipe architecture et fonctionnement des espèces fruitières INRA, Bat. 33, 2 Place Viala, F34060 Montpellier Cedex 1

\section{ARTICLE}

Olive, Olea europaea L., is a mediterranean fruit species that is cultivated mainly for oil but also for canned fruits. Because of the traditional cultivation, most orchards include several cultivars. Numerous cases of homonymy (one denomination for several genotypes) and synonymy (one genotype with several denominations) could occur in different traditional olive areas. Recently in France, a regular increase in cultivated surface is noted leading to the increase of plant multiplication by cuttings. According to the conditions on health and pomological qualities defined by European Union (Directives 93/48 and 93/79), the nursery men have to ensure the conformity of plant material based on morphological descriptors. However, because of most discriminating characters are related to olive fruit, morphological characterisation has to be completed by a molecular approach.Isozymes were the first genetic markers used in olive fingerprinting [1, 2]. However, their usefulness has been limited due to the small number of isozyme systems available, the low level of polymorphism obtained, and the influence of environmental factors. The emergence of new PCR-based molecular markers, such as RAPD, AFLP, and SSR, has created the opportunity for fine-scale genetic characterisation of germplasm collections because they are highly polymorphic and are not influenced by environmental conditions (see also review by Wünsch and Hormaza [3]). RAPD and AFLP markers have been previously used for cultivar characterisation in olive $[4,5,6]$, but because of the use of arbitrary sequences these markers can not be exchanged among laboratories according to standardized protocols [7]. Because of specific loci, microsatellite markers (Simple Sequence Repeat, SSR) were reproducible and can be used by different laboratories with comparable results. Recently, SSR loci were developed on olive $[8,9,10,11]$.As a first step for exploring the usefulness of SSR loci in french olive characterisation, we analysed a set of accessions using SSR loci and the sequencer Abi 3100. Our aim was to select the most discriminating combination of SSR markers and to provide a basis for establishing a database of genotype reference for each of french olive cultivar.

\section{Material and methods}




\section{Plant material}

A total of 58 accessions corresponding to 54 french olive cultivar denominations were analysed (table 1). Among these cultivars, 13 are considered as the main french olive cultivars and the others as minor and local ones. The accessions were issued from the national germplasm collection at the "Conservatoire botanique national méditerranéen de Porquerolles" (CBNMP), from the INRA germplasm at Montpellier, and from nurseries or producers (table 1). For "Germaine", "Noirette" and "Rougette de Pignan", 2, 3 and 2 accessions were analysed respectively.

Table 1 List of french olive cultivars studied and their origin.

\begin{tabular}{|c|c|c|c|}
\hline Cultivar name & Source & Cultivar name & Source \\
\hline Aglandau* & $\operatorname{Rey}^{2}$ & Grosse Violette & Vialatte $^{3}$ \\
\hline Amellau* & INRA Montpellier $^{1}$ & Grosselotte & Théron $^{3}$ \\
\hline Aubenc & Breysse $^{3}$ & Lucques* & CBNMP $^{1}$ \\
\hline Averaude & CBNMP $^{1}$ & Menudel & CBNMP $^{1}$ \\
\hline Baguet & CBNMP $^{1}$ & Moncita & $\sqrt{\text { INRA Montpellier }}$ \\
\hline Bé dé Cézé & Cordier $^{3}$ & Moufla & INRA Montpellier \\
\hline Béchude & Martre $^{2}$ & Négrette & Vigouroux ${ }^{3}$ \\
\hline Belgentiéroise & INRA Montpellier ${ }^{1}$ & Noirette $^{1}$ & CBNMP $^{1}$ \\
\hline Besse & Pontier $^{3}$ & Noirette $^{2}$ & Rey $^{2}$ \\
\hline Blanc de Payzac & Vigouroux ${ }^{3}$ & Noirette $^{3}$ & Delenne $^{3}$ \\
\hline Blanchet & Massot $^{3}$ & Olivière* & Penel $^{2}$ \\
\hline Bouquetière & Prat $^{3}$ & Petit Ribier & Rey $^{2}$ \\
\hline Bouteillan* & CBNMP $^{1}$ & Picholine* & Penel $^{2}$ \\
\hline Brun & $\operatorname{Rey}^{2}$ & Pigale & INRA Montpellier \\
\hline Cailletier* & CBNMP $^{1}$ & Piquette & Martre $^{2}$ \\
\hline Cayanne & $\mathrm{Rey}^{2}$ & Ronde de $\mathrm{VdB}^{4}$ & Vialatte $^{3}$ \\
\hline Cayet blanc & $\operatorname{Rey}^{2}$ & Rougette de l'Ardèche & Cordier $^{3}$ \\
\hline
\end{tabular}




\begin{tabular}{|c|c|c|c|}
\hline Cayet roux* & $\operatorname{Rey}^{2}$ & Roussette de l'Ardèche & Rey $^{2}$ \\
\hline Cayon* & INRA Montpellier $^{1}$ & Rouget de l'Hérault & CBNMP $^{1}$ \\
\hline Clermontaise & $\operatorname{Rey}^{2}$ & Rougette de Pignan $^{1}$ & CBNMP $^{1}$ \\
\hline Colombale & CBNMP $^{1}$ & Rougette de Pignan $^{2}$ & $\operatorname{Rey}^{2}$ \\
\hline Corniale & Massot $^{3}$ & Sabina & Demoustier $^{2}$ \\
\hline Cul blanc & Martre $^{2}$ & Salonenque* & Penel $^{2}$ \\
\hline Darame & Ramade $^{3}$ & Tanche* & $\overline{B R L^{2}}$ \\
\hline Dorée & CBNMP $^{1}$ & Ubac & $\operatorname{Rey}^{2}$ \\
\hline Germaine $^{1}$ & CBNMP $^{1}$ & Verdale $\mathrm{BdR}^{5}$ & CBNMP $^{1}$ \\
\hline Germaine $^{2}$ & Demoustier $^{2}$ & Verdale de l'Ardèche & Nébon $^{3}$ \\
\hline Grapié & CBNMP $^{1}$ & Verdale de l'Hérault* & Penel $^{2}$ \\
\hline Grossane* & |NRA Montpellier ${ }^{1}$ & Vermillau & CBNMP $^{1}$ \\
\hline
\end{tabular}

${ }^{1}$ From olive collection.

${ }^{2}$ From nursery.

${ }^{3}$ From producer.

${ }^{4} \mathrm{VdB}=$ Villeneuve de Berg

${ }^{5} B d R=$ Bouches du Rhône.

${ }^{*}$ Main french cultivar.

\section{DNA preparation}

DNA was extracted following the protocol described by Besnard et al. [12] with modifications. About $1 \%$ of polyvinylpyrrolidone (PVP 40.000) was added to the $2 \times$ CTAB buffer.

\section{SSR analysis}

Among SSR loci developed by Carriero et al. [10] and Cipriani et al. [11], 20 SSR loci were selected because they produced clear bands with expected size. According to the annealing temperature and to the range size of alleles detected, four combinations with 4 SSR loci per combination were defined for SSR genotyping using the sequencer Abi 3100. For each combination, two PCRs were performed with two primer pairs per PCR. For the first primer pair, the reverse or forward primer had tail M13 
sequence and for the second tail T7 sequence [13].

The PCR reaction was conducted in the total volume of $20 \mu \mathrm{l}: 1.5 \mathrm{mM} \mathrm{MgCl} 2,0.16 \mathrm{mM}$ of each dNTP, 3 pmol of locus specific primers with tail M13 and T7, 3 pmol of fluorescent tail T7 and M13, 0.2 pmol of locus specific primers without tail, 1 unit of Taq polymerase (Qiagen). The PCR was carried out using a PTC 100 thermocycler (MJ Research). After 3 min at $94^{\circ} \mathrm{C}, 35$ cycles were performed with $1 \mathrm{~min}$ at $94^{\circ} \mathrm{C}, 1 \mathrm{~min}$ at $57^{\circ} \mathrm{C}$ and $1 \mathrm{~min}$ at $72{ }^{\circ} \mathrm{C}$ and a final extension step of $5 \mathrm{~min}$ at $72{ }^{\circ} \mathrm{C}$.

\section{Data analysis}

SSR data were scored and verified using Genescan and Genotyper software. For each SSR loci, expected heterozygosity values were computed under the Hardy-Weinberg hypothesis according to the no-bias model [14] using Genetics 4.0 software [15]. Significance of heterozygote deficiency was assessed using exact test and Genepop 3.1b software [16]. The probability of obtaining a given genotype was calculated under the hypothesis of independence between markers as the product of the corresponding allele frequency for each locus of the pattern $\mathrm{i}: \mathrm{Pi}=\Pi \mathrm{fj}$. Discriminating power of each SSR locus was calculated as follows: $D j=1-\Sigma p_{i}\left(N p_{i}-1\right) /(N-1)$ where $p_{i}$ was the frequency of the $\mathrm{i}$-th molecular pattern revealed by locus $\mathrm{j}$, and $\mathrm{N}$ was the number of genotypes [17].

Relationships between olive genotypes were based on a binary matrix and estimated according to the Jaccard similarity coefficient, taking the presence of bands into account only. A phenogram was drawn using the UPGMA algorithm.

\section{Results and discussion}

\section{SSR polymorphism}

A total of 54 alleles were obtained using 12 SSR loci. The number of alleles per locus varied from 2 (loci UDO99-004 and UDO99-019) to 8 (GAPU 101 locus) with an average of 4.5 alleles per locus (table 2)( Table 2 ). Observed heterozygosity ranged from 0.097 for the UD099-019 locus to 0.968 for the GAPU 101 locus with an average for all loci of 0.581 . Compared to the expected heterozygosity value, a significant heterozygote deficiency was observed for UDO99-006 and UD099-034 loci, probably due to the occurrence of null alleles.

Table 2 Genetic parameters and discriminating power of SSR loci calculated on 58 olive genotypes.

\begin{tabular}{|c|c|c|c|c|c|c|c|}
\hline $\begin{array}{l}\text { Primer } \\
\mathbf{S}\end{array}$ & Repeat motif & $\begin{array}{l}\text { Numb } \\
\text { er of } \\
\text { alleles }\end{array}$ & $\mid \begin{array}{l}\text { Size } \\
\text { rang } \\
\text { e } \\
\text { (bp) }\end{array}$ & $\begin{array}{l}\text { Expected } \\
\text { heterozygosi } \\
\text { ty }\end{array}$ & $\begin{array}{l}\text { Observed } \\
\text { heterozygosi } \\
\text { ty }\end{array}$ & $\begin{array}{l}\text { No of } \\
\text { molecul } \\
\text { ar } \\
\text { profiles }\end{array}$ & \begin{tabular}{|ll}
\multicolumn{2}{|c}{ Discriminati } \\
ng & power \\
(D) &
\end{tabular} \\
\hline $\begin{array}{l}\text { GAPU } \\
101^{\mathrm{a}, 1}\end{array}$ & $(G A) 8(G) 3(A G) 3$ & 8 & $205-$ & 0.840 & 0.968 & 20 & 0.943 \\
\hline $\begin{array}{l}\text { UDO9 } \\
9-014\end{array}$ & (GT)10 & 4 & $\begin{array}{l}115- \\
138\end{array}$ & 0.714 & 0.613 & 10 & 0.861 \\
\hline
\end{tabular}




\begin{tabular}{|c|c|c|c|c|c|c|c|}
\hline$\overline{b, 2}$ & & & & & & & \\
\hline $\begin{array}{l}\text { UDO9 } \\
9-006 \\
b, 2\end{array}$ & $(\mathrm{GT}) 5(\mathrm{AT}) 6 \mathrm{G}(\mathrm{GT}) 6$ & 7 & $\mid \begin{array}{l}178- \\
198\end{array}$ & 0.710 & $0.193 * *$ & 13 & 0.850 \\
\hline $\begin{array}{l}\text { UDO9 } \\
9-036 \\
b, 1\end{array}$ & (GT)19(AG)5 & 7 & \begin{tabular}{||l}
$161-$ \\
183
\end{tabular} & 0.719 & 0.806 & 10 & 0.846 \\
\hline $\begin{array}{l}\text { GAPU } \\
59^{a, 1}\end{array}$ & $(\mathrm{CT}) 9$ & 6 & $\mid \begin{array}{l}226- \\
245\end{array}$ & 0.611 & 0.742 & 8 & 0.833 \\
\hline $\begin{array}{l}\text { UDO9 } \\
9- \\
044^{b, 1}\end{array}$ & $\left(\begin{array}{l}(\mathrm{TG}) 7 \mathrm{G}(\mathrm{TG}) 2(\mathrm{G}) 3(\mathrm{TG}) 2(\mathrm{TGC} \\
\mathrm{G}) 5\end{array}\right.$ & 4 & $\begin{array}{l}144- \\
171\end{array}$ & 0.571 & 0.678 & 7 & 0.793 \\
\hline $\begin{array}{l}\text { UDO9 } \\
9-041 \\
b, 1\end{array}$ & (CA)18 & 3 & $\begin{array}{l}89- \\
117\end{array}$ & 0.510 & 0.548 & 5 & 0.788 \\
\hline $\begin{array}{l}\text { UDO9 } \\
9-005 \\
b, 2\end{array}$ & $(\mathrm{AC}) 9$ & 3 & $\mid \begin{array}{l}155- \\
163\end{array}$ & 0.630 & 0.839 & 6 & 0.776 \\
\hline $\begin{array}{l}\text { UDO9 } \\
9- \\
034^{b, 1}\end{array}$ & (TG)23 & 5 & $\mid \begin{array}{c}95- \\
131\end{array}$ & 0.548 & $0.355^{*}$ & 9 & 0.763 \\
\hline $\begin{array}{l}\text { UDO9 } \\
9-027 \\
b, 1\end{array}$ & (A)19 & 3 & $\mid \begin{array}{l}133- \\
213\end{array}$ & 0.514 & 0.548 & 6 & 0.701 \\
\hline $\begin{array}{l}\text { UDO9 } \\
9- \\
004^{b, 2}\end{array}$ & $(\mathrm{AC}) 10$ & 2 & $\mid \begin{array}{l}163- \\
167\end{array}$ & 0.465 & 0.581 & 3 & 0.511 \\
\hline $\begin{array}{l}\text { UDO9 } \\
9- \\
019^{b, 2}\end{array}$ & (GT)20(AT)5 & 2 & $\mid \begin{array}{l}115- \\
147\end{array}$ & 0.094 & 0.097 & 3 & 0.252 \\
\hline
\end{tabular}

${ }^{a}$ primers developed by Carriero et al. (2002).

brimers developed by Cipriani et al. (2002).

${ }^{1}$ primers with $\mathrm{T} 7$ tail.

${ }^{2}$ primers with M13 tail. 


\section{Olive genotyping}

Analysis of 58 olive accessions using 54 SSR alleles revealed 58 different molecular patterns ( (figure 1) ). About $98.97 \%$ of the genotype pairs were differentiated by 7 to 25 alleles since among 1653 pairwise comparisons, only 17 molecular profile pairs were distinguished by 1 to 6 alleles (table 3 ) and ( figure 2) ). The distribution of genetic difference in pairwise comparisons displayed a main mode which was centred at 16-18 difference ( (figure 2)). Under the hypothesis of non-linkage between SSR alleles, the probability of obtaining a given molecular pattern was very low and ranged from $8.5810^{-11}$ for Tanche to $4.8610^{-6}$ for Belgentiéroise. The discriminating power for each SSR locus varied from 0.943 to 0.252 (table 2). The lowest values were observed for UDO99-004 and UDO99-019 loci because only 2 alleles were detected in 3 genotypes. Discriminating power variation among SSR loci was due to either the number of alleles per locus and their frequency. Although the low number of alleles, the locus UDO99-014 was more discriminating than UD099-006, UDO99-036 and GAPU 59 loci because the frequency of three UDO99-014 alleles varied from 0.328 to 0.552 while most allele frequencies of the other loci were low or high (14 among 20 alleles). A total of 13 combinations of loci were tested according to their discriminating power in order to identify the most efficient combination for genotype discrimination (table 4). Starting with the most discriminating, one locus was added for each successive combination. Genotype discrimination was not improved by adding UDO99-041, UDO99-034, UDO99-019 loci to the combination No 6, 8 and 11 respectively since the number of indistinguishable pairs of genotypes was not modified compared to the results obtained by the previous combination. The most efficient combination was obtained by excluding UD099-041, UD099-005, UD099-034 and UD099-019 loci which were less informative than the other eight loci (combination No 13).

Table 3 Number of distinct SSR markers between the most similar pair-wise accessions (upper part of the table) or between accessions of the same denomination (middle part of the table) or nearly the same denomination (lower part of the table).

\begin{tabular}{|c|c|c|}
\hline \multicolumn{2}{|l|}{ Comparison } & \multirow[t]{2}{*}{ Nb of SSR markers* } \\
\hline Accession 1 & Accession 2 & \\
\hline Rougette de l'Ardèche & Bouquetière & 1 \\
\hline Verdale de l'Hérault & Averaude & 1 \\
\hline Blanchet & Blanc de Payzac & 2 \\
\hline Bouquetière & Béchude & 2 \\
\hline Germaine 1 & Cailletier & || 2 \\
\hline Grosselotte & Averaude & 2 \\
\hline Petit Ribier & Germaine 2 & |3 \\
\hline
\end{tabular}




\begin{tabular}{|c|c|c|}
\hline Rougette de l'Ardèche & Béchude & 3 \\
\hline Verdale de l'Hérault & Grosselotte & |3 \\
\hline Noirette 3 & Négrette & 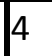 \\
\hline Colombale & Averaude & 5 \\
\hline Grapié & Aglandau & 5 \\
\hline Grossane & Averaude & 5 \\
\hline Grosselotte & Grossane & $\mid 5$ \\
\hline Piquette & Picholine & 6 \\
\hline Verdale de l'Hérault & Colombale & 6 \\
\hline Verdale de l'Hérault & Grossane & 6 \\
\hline Germaine 1 & Germaine 2 & 11 \\
\hline Noirette 1 & Noirette 2 & 19 \\
\hline Noirette 1 & Noirette 3 & 15 \\
\hline Noirette 2 & Noirette 3 & 20 \\
\hline Rougette de Pignan 1 & Rougette de Pignan 2 & 17 \\
\hline Rougette de Pignan 1 & Rougette de l'Ardèche & 22 \\
\hline Rougette de Pignan 1 & Rougette de l'Hérault & 10 \\
\hline Rougette de Pignan 2 & Rougette de l'Ardèche & 15 \\
\hline Rougette de Pignan 2 & Rougette de l'Hérault & 15 \\
\hline Rougette de l'Ardèche & Rougette de l'Hérault & 18 \\
\hline Verdale de l'Ardèche & Verdale Bouches du Rhône & 20 \\
\hline Verdale de l'Ardèche & Verdale de l'Hérault & 10 \\
\hline Verdale Bouches du Rhône & Verdale de l'Hérault & 16 \\
\hline
\end{tabular}

*Pair-wise distinct markers 
Table 4 Genetic Efficiency of a primer combination and probability of getting a genotype under the independence hypothesis.

\begin{tabular}{|c|c|c|c|}
\hline $\begin{array}{l}\mathrm{N}^{\circ} \\
\text { combination }\end{array}$ & Primers & $\begin{array}{l}\text { Number of } \\
\text { pairs }\end{array}$ & $\begin{array}{l}\text { Probability range of } \\
\text { getting a genotype }\end{array}$ \\
\hline 1 & GAPU 101 & 95 & $2.5410^{-3}-7.2310^{-2}$ \\
\hline 2 & GAPU 101, UD099-014 & 20 & $1.7610^{-4}-1.0610^{-2}$ \\
\hline 3 & GAPU 101, UD099-014, UD099-006 & 10 & $5.1610^{-7}-1.7210^{-3}$ \\
\hline 4 & GAPU 101, UD099-014, UD099-006, UD099-036 & 9 & $3.2110^{-8}-1.0610^{-4}$ \\
\hline 5 & $\mid \begin{array}{l}\text { GAPU 101, UDO99-014, UDO99-006, UDO99-036, } \\
\text { GAPU } 59\end{array}$ & 7 & $4.3510^{-10}-2.4710^{-5}$ \\
\hline 6 & $\mid \begin{array}{l}\text { GAPU 101, UDO99-014, UDO99-006, UDO99-036, } \\
\text { GAPU 59, UDO99-044 }\end{array}$ & 3 & $1.1610^{-10}-6.5610^{-6}$ \\
\hline 7 & $\mid \begin{array}{l}\text { GAPU 101, UDO99-014, UD099-006, UD099-036, } \\
\text { GAPU 59, UDO99-044, UDO99-041 }\end{array}$ & 3 & $8.5810^{-11}-4.8610^{-6}$ \\
\hline 8 & $\mid \begin{array}{l}\text { GAPU 101, UDO99-014, UDO99-006, UD099-036, } \\
\text { GAPU 59, UDO99-044, UDO99-041, UD099-005 }\end{array}$ & 2 & $8.5810^{-11}-4.8610^{-6}$ \\
\hline 9 & $\mid \begin{array}{l}\text { GAPU 101, UDO99-014, UD099-006, UD099-036, } \\
\text { GAPU 59, UDO99-044, UD099-041, UD099-005, } \\
\text { UD099-034 }\end{array}$ & 2 & $8.5810^{-11}-4.8610^{-6}$ \\
\hline 10 & $\mid \begin{array}{l}\text { GAPU 101, UDO99-014, UDO99-006, UDO99-036, } \\
\text { GAPU 59, UDO99-044, UD099-041, UD099-005, } \\
\text { UDO99-034, UD099-027 }\end{array}$ & 1 & $8.5810^{-11}-4.8610^{-6}$ \\
\hline 11 & $\mid \begin{array}{l}\text { GAPU 101, UDO99-014, UDO99-006, UDO99-036, } \\
\text { GAPU 59, UDO99-044, UD099-041, UDO99-005, } \\
\text { UDO99-034, UD099-027, UD099-004 }\end{array}$ & 0 & $8.5810^{-11}-4.8610^{-6}$ \\
\hline 12 & All SSR loci & 0 & $8.5810^{-11}-4.8610^{-6}$ \\
\hline 13 & $\mid \begin{array}{l}\text { GAPU 101, UDO99-014, UDO99-006, UDO99-036, } \\
\text { GAPU 59, UDO99-044, UDO99-027, UDO99-004 }\end{array}$ & 0 & $1.1610^{-10}-6.5610^{-6}$ \\
\hline
\end{tabular}

aindistinguishable pairs of genotypes.

\section{Cultivar identification}


Each of the 58 olive accessions was characterised by a specific molecular profile with a very low probability to obtain a given genotype under random association. However, 17 accession pairs were only distinguished by 1 to 6 alleles and further loci should be examined in order to validate cultivar characterisation especially for accession pairs which were differentiated by 1 or 2 alleles (table 3 and ( figure 1) ). The 12 SSR loci used in the present study were selected among 20 loci developed by Carriero et al. [10] and Cipriani et al. [11]. Further loci among those developed by the two previous studies and also among loci developed by Sefc et al. [9] and by Rallo et al. [8] can be used in the complementary study. Selection of the 12 SSR loci for their polymorphism information was conducted on a subset of 7 french cultivars representing the genetic diversity in French olive based on RAPD markers $[18,19]$. In the complementary study, selection of SSR loci should be based on genetic diversity obtained by the present work and the selected SSR loci should be added to the previous set (SSR loci of the combination No 13) defined as the best combination for genotype discrimination. In fact, eight SSR loci were sufficient to distinguish the 58 olive accessions with a low probability to obtain a given genotype (ranged between $1.1610^{-10}$ to $6.5610^{-6}$; table 4).

Two contrasting cases on genetic characterisation of olive cultivar were noted in the present study. First, beyond to validation of genotype discrimination of the 17 accession pairs which were distinguished only by 1 to 6 alleles, we can not conclude on the genetic relationships among these cultivars: are they really genetically close or is it because of the limited number of markers? Comparisons with previous studies on the french olive germplasm $[6,19]$ are not possible because several accessions were not analysed. However, the relative genetic similarity between "Cailletier" and "Germaine" noted in the present study was confirmed by the previous work [6]. Second, the accessions under the same denomination were very distinct among them and the genetic discrimination was validated by 10 to 22 distinct alleles (table 3). For "Rougette" denomination, three cultivars referred to their origin of location were distinguished: "Rougette de l'Ardèche", "Rougette de l'Hérault" and "Rougette de Pignan". The same case was observed for "Verdale" denomination. In contrast, 5 cases of homonymy were noted for "Germaine", "Noirette" and "Rougette de Pignan" denominations (table 3). In these cases, the accessions analysed were issued from different locations including the germplasm collection at the CBNMP (table 1). We have no objective criterion to determine which genotype typifies "Germaine", "Noirette" or "Rougette de Pignan" cultivars. The question is also relevant for all other genotypes characterised in the present study. As proposed by Khadari et al. [6, 19], a genotype reference for one olive cultivar is defined when several olive trees, grouped under the same denomination presenting similar morphological characters and originated from different collections, nurseries and orchards, display the same molecular pattern. Conversely, choosing one or several genotypes as reference for genetically heterogenous denominations as "Germaine", "Noirette" and "Rougette de Pignan" cases should take into account the relative importance of cultivation among the clones as well as the opinion of the olive producers.

\section{Conclusion}


This work represents a first step to use and validate SSR loci for olive cultivar characterisation. A set of 8 SSR loci was selected as the best loci combination for genotype discrimination, but further efficient SSR loci should be added to validate molecular characterisation of olive cultivar. This study is also a part of an establishing database of genotype reference for each French olive cultivar. In the work in progress, at least 3 accessions of the same denomination issued from different locations are analysed by SSR loci.

\section{Acknowledgments}

We wish to thank all the people who provided olive tree samples for this study, especially J.P. Roger from CBNMP. We are particularly indebted to C. Brachet for her help in earlier preparing plant material for DNA extraction and to C. Grout for her help in testing SSR primers. During the whole study, the encouragement and help of Dr. F. Boillot (CBNMP) and Dr. S. Santoni (INRA) were decisive. This research was supported by funding from ONIOL (Office national interprofessionnel des oléagineux, protéagineux et cultures textiles).

\section{References}

1 OUAZZANI N, LUMARET R, VILLEMUR P. Apport du polymorphisme alloenzymatique à l'identification variétale de l'olivier. Agronomie 1996; 15: 31-7.

2 TRUJILLO I, RALLO L, ARUS P. Identifying olive cultivar by isozyme analysis. J Amer Soc Hort Sci 1995; 120: 318-24.

3 WÜNSCH A, HORMAZA JI. Cultivar identification and genetic fingerprinting of temperate fruit tree species using DNA markers. Euphytica 2002; 125: 59-67.

4 ANGIOLILLO A, MENCUCCINI M, BALDONI L. Olive genetic diversity assessed using amplified fragment length polymorphisms. Theor Appl Genet 1999; 98: 411-21.

5 BESNARD G, BRETON C, BARADAT P, KHADARI B, BERVILLÉ A. Cultivar Identification in Olive based on RAPD markers. J Amer Sc Hort Sci 2001; 126(6): 668-75.

6 KHADARI B, BRETON C, MOUTIER N, ROGER JP, BESNARD G, BERVILLÉ A, DOSBA F. The use of molecular markers for germplasm management in French olive collection. Theor Appl Genet 2003; 106: 521-9.

7 JONES CJ, EDWARDS KJ, CASTAGLIONE S. Reproductibility testing of RAPD, AFLP and SSR markers in plants by a network of European laboratories. Mol Breeding 1997; 3: 381-90.

8 RALLO P, DORADO G, MARTIN A. Development of simple sequence repeats (SSRs) in the olive tree (Olea europaea L.). Theor Appl Genet 2000; 101: 984-9.

9 SEFC KM, LOPES MS, MENDONCA D, et al. Identification of microsatellite loci olive (Olea europaea) 
and their characterization in Italian and Iberian olive trees. Mol Ecol 2000; 9: 1171-3.

10 CARRIERO F, FONTANAZZA G, CELLINI F, GIORIO G. Identification of simple sequence repeats (SSRs) in olive (Olea europaea L.). Theor Appl Genet 2002; 104: 301-7.

11 CIPRIANI G, MARRAZZO MT, MARCONI R, CIMATO A, TESTOLIN R. Microsatellite markers isolated in olive (Olea europaea L.) are suitable for individual fingerprinting and reveal polymorphism within ancient cultivars. Theor Appl Genet 2002; 104: 223-8.

12 BESNARD G, KHADARI B, VILLEMUR P, BERVILLÉ A. Cytoplasmic male sterility in the olive (Olea europaea L.). Theor Appl Genet 2000; 100: 1018-24.

13 GANACHE BI, RAPOSO M, RAYMOND M, DESCHEPPER CF. M13-tailed primers improve the readability and usability of microsatellite analyses performed with two different allele-sizing methods. Biotechniques 2001; 31(1): 24-8.

14 NEI M. Estimation of average heterozygosity and genetic distances from a small number of individuals. Genetics 1978; 89: 583-90.

15 BELKHIR K. Genetix, version 4.0. A Windows Program for Population Genetics Analysis. Laboratoire Génome, Populations, Interactions. Montpellier, France: CNRS UPR 9060, Université Montpellier II, 1999.

16 RAYMOND M, ROUSSET F. An exact test for population differentiation. Evolution 1995; 49: 12803.

17 TESSIER C, DAVID J, THIS P, BOURSIQUOT JM, CHARRIER A. Optimization of the choice of molecular markers for varietal identification in Vitis vinifera L. Theor Appl Genet 1999; 98: 171-7. 18 BESNARD G, BARADAT P, BERVILLÉ A. Genetic relationships in the olive (Olea europaea L.) reflect multilocal selection of cultivars. Theor Appl Genet 2001; 102: 251-8.

19 KHADARI B, MOUTIER N, DOSBA F. Approche moléculaire de la caractérisation des varieties françaises d'olivier: construction d'une base de données de genotypes de reference. Olivae 2001; 87: 29-32. 


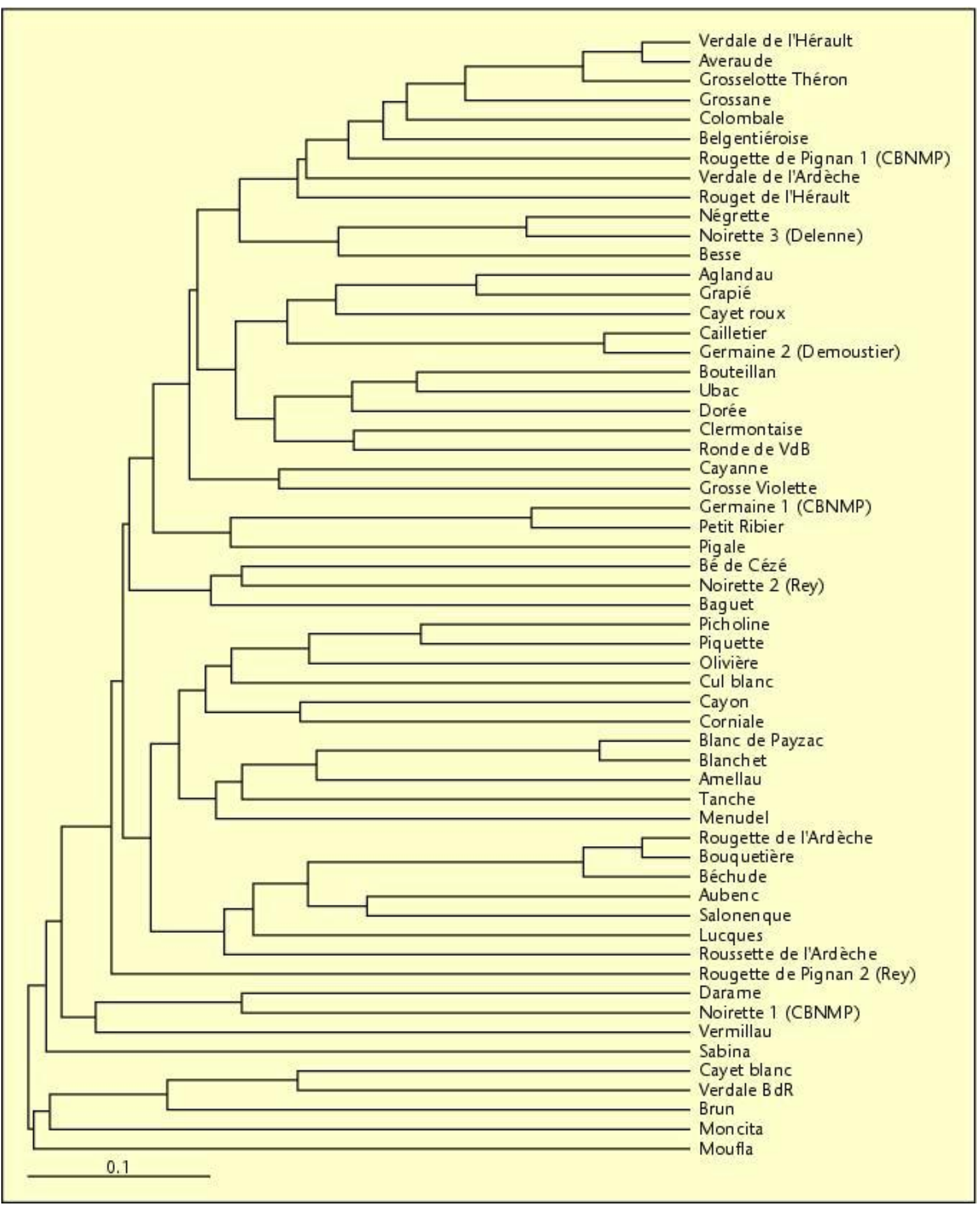

Figure 1 Classification of the french olive cultivars. The phenogram is based on UPGMA cluster analysis of the Jaccard coefficient similarity. 


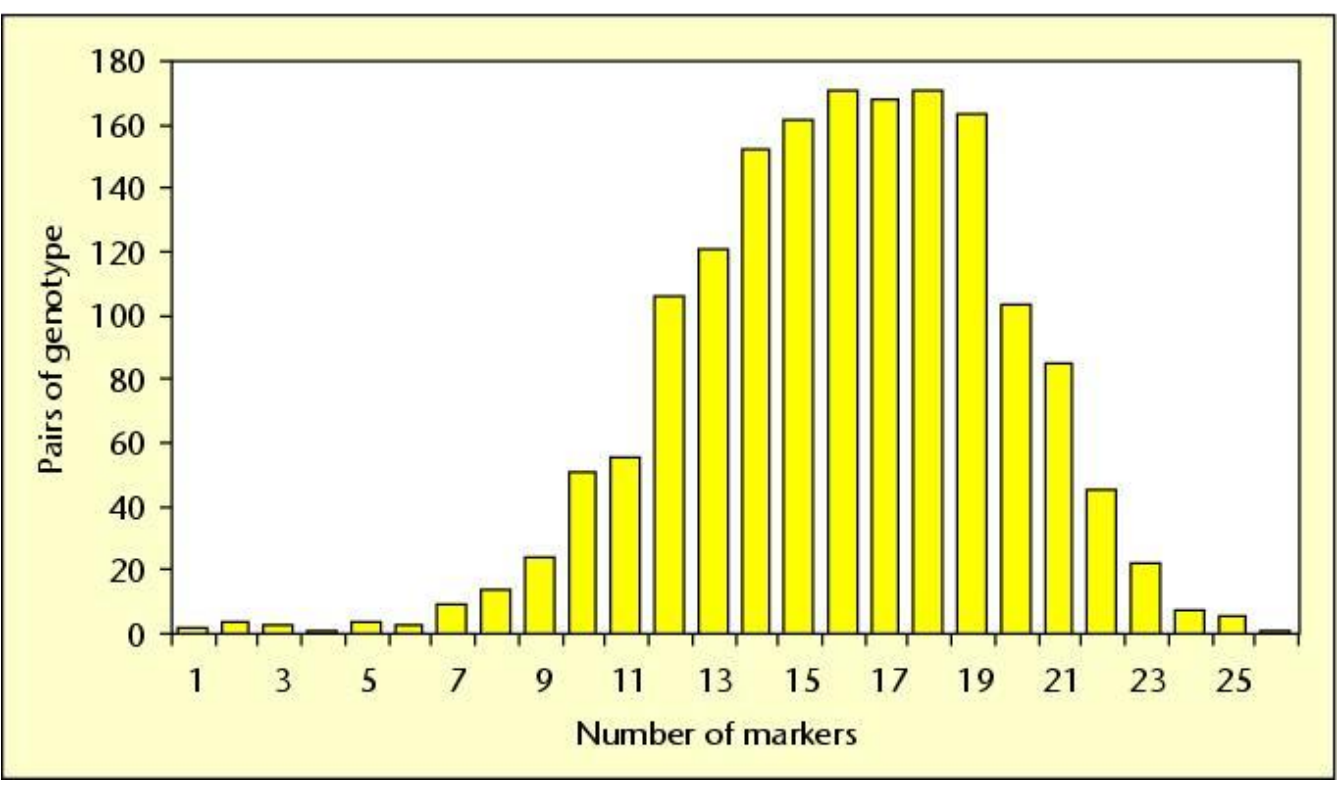

Figure 2 Frequency distribution of genetic dissimilarity for all pairwise combinations among 58 olive genotypes. 